\title{
KONSEP EKONOMI PADA MASA RASULULLAH NABI MUHAMMAD SAW
}

\section{Dian Septiani (90100118025)}

Kelakuan manusia di bumi dalam memenuhi suatu kebutuhan-kebutuhannya pada zaman dahulu cenderung mengalami proses yang sama, bagaimana cara berburu, meramu dan bercocok tanam. Begitu pula dengan perilaku manusia saat ini, mengalami kecenderungan ke arah yang sama, bagaimana mendapatkan pekerjaan, mempertahankan dan menyelesaikannya. Hal ini menandakan bahwa manusia memiliki pola perilaku untuk memenuhi kebutuhan yang relative sama walaupun tidak persis. Proses ini yang berulang dari pemenuhan kebutuhan ini menjadikan manusia dapat mengidentifikasi, mengklasifikasi dan memverifikasi pola perilaku yang lebih efektif dalam memenuhi kebutuhan hidupnya. Akhirnya manusia dapat memodifikasi penandaan pola perilaku tersebut dalam sikap, bagaimana melakukan sesuatu kegiatan untuk mendapatkan keuntungan maksimal dan menghindari kerugian seminimal mungkin dari setiap pemenuhan kebutuhan, dan manusia dalam pemenuhan kebutuhan tersebut memiliki kebebasan, yang merupakan unsur dasar manusia dalam mengatur dirinya. ${ }^{1}$

Pada masa Islam, hakam atau juru damai itu harus memenuhi beberapa kualifikasi. Di antara syarat yang terpenting bagi mereka adalah harus cakap dan memiliki kekuatan supranatural atau adikodrati. Oleh karena itu, dalam pemeriksaan dan penyelesaian persengketaan di kalangan mereka, hakam lebih banyak menggunakan kekuatan firasat daripada menghadirkan alat-alat bukti seperti saksi-saksi atau pengakuan. Namun setelah Islam datang dan berkembang yang dibawakan oleh Nabi Muhammad Saw, lembaga perwasitan terus berjalan dan dikembangkan sebagai alternatif penyelesaian sengketa dengan memodifikasi yang pernah berlaku pada masa pra-Islam. Perkembangan sekarang ini, penyelesaian sengketa ekonomi Islam yang dulunya diselesaikan melalui Badan Arbitrase Syariah sudah dapat diselesaikan melalui lembaga peradilan yang ada. Yaitu Peradilan Agama di Indonesia. Hal ini berkaitan erat dengan diperluasnya kompetensi Peradilan Agama melalui Revisi Undang-Undang Peradilan Agama No.7 Tahun 1989 menjadi Undang-Undang No.3 Tahun 2006. Melalui Pasal 49 UU No.3 Tahun 2006 ini diatur kewenangan Peradilan Agama selain menyelesaikan sengketa-sengketa hukum

\footnotetext{
${ }^{1}$ Rangkuti, R. Y. (2011). "Sistem Penyelesaian Sengketa Ekonomi Islam: Instrumen Penting bagi Konsep Ekonomi Islam Mendatang". Asy-Syir'ah: Jurnal Ilmu Syari'ah Dan Hukum, Vol 45(2).
} 
keluarga, seperti perkawinan, perceraian, pengasuhan anak, waris, wasiat, hibah diperluas kewenangannya untuk menyelesaikan sengketa ekonomi Islam. ${ }^{2}$

Adapun perjalanan hidup Nabi Muhammad SAW yang Mempelajari sekaligus mengkaji keilmuan yang luar biasa, serta kaya dalam mencerahkan sesuatu. Oleh karena itu Manusia merupakan tauladan Nabi Muhammad yang mencakup segala aspek kehidupan sehingga tak habis-habisnya untuk dikaji secara terus menerus. Belum mampunya umat islam mengambil suri tauladan Nabi Muhammad SAW secara holistic dan komprehensif dikarenakan kurangnya kesadaran dalam mengkaji islam, dan ketidakmampuan melihat perjalanan hidup Rasulullah SAW secara lengkap dan holistic baik dari dimensi social, politik, militer, edukasi, dan legal yang kemudian menformulasikan nilai-nilai ketauladanan tersebut kedalam suatu model yang dapat di teladani dengan mudah. Salah satu kriteria kesuksesan seseorang adalah keberhasilan dalam memimpin keluarga. Nabi Muhammad SAW adalah suri tauladan yang baik dalam kepemimpinan keluarga. Meskipun banyak kritikan yang di berikan kepada beliau oleh kalangan non-muslim, berkaitan dengan rumah tangga beliau, Nabi Muhammad SAW sosok yang baik dalam kepemimpinannya. ${ }^{3}$

\footnotetext{
${ }^{2}$ Efyanti, Y., \& Ekonomi, I. D. (2015). JYasni Efyanti, Islam Dan Ekonomi[. 15, 15-30.

${ }^{3}$ Umam, M. K. (2018). Imam Para Nabi : Menelusur Jejak Kepemimpinan Dan. 60 Jurnal Al-Hikmah, 6 no., 59-74.
} 


\section{DAFTAR PUSTAKA}

Rangkuti, R. Y. (2011). Sistem Penyelesaian Sengketa Ekonomi Islam: Instrumen Penting bagi Konsep Ekonomi Islam Mendatang. Asy-Syir'ah: Jurnal Ilmu Syari’ah Dan Hukum, Vol 45(2).

Efyanti, Y., \& Ekonomi, I. D. (2015). ]Yasni Efyanti, Islam Dan Ekonomi[. 15, 15-30.

Umam, M. K. (2018). Imam Para Nabi : Menelusur Jejak Kepemimpinan Dan. 60 Jurnal AlHikmah, 6 no., 59-74. 